\title{
Hydrodynamic and tidal controls of small-scale phytoplankton patchiness
}

\author{
Laurent Seuront ${ }^{1,2, *}$ \\ ${ }^{1}$ Ecosystem Complexity Research Group, Station Marine de Wimereux, CNRS UMR 8013 ELICO, \\ Université des Sciences et Technologies de Lille, 28 avenue Foch, 62930 Wimereux, France \\ ${ }^{2}$ School of Biological Sciences, Flinders University, GPO Box 2100, Adelaide 5001, South Australia, Australia
}

\begin{abstract}
A continuous time series of high-resolution in vivo fluorescence measurements in coastal waters of the eastern English Channel over 4 tidal cycles investigated the potential influence of different turbulence intensities and advective tidal processes on small-scale phytoplankton patchiness. Although small-scale phytoplankton patchiness decreased with increasing turbulence intensity, phytoplankton distributions were never fully homogenised, and were more patchy during ebb than flood tides at turbulence intensities ranging from $10^{-7}$ to $10^{-4} \mathrm{~m}^{2} \mathrm{~s}^{-3}$. A combination of biologically and physically driven patchiness is suggested to be the cause of the observed patterns.
\end{abstract}

KEY WORDS: Turbulence · Tide - Phytoplankton · Patchiness - Sampling · Phaeocystis globosa

\section{INTRODUCTION}

In the marine environment, patchy distributions of phytoplankton have been documented at scales of centimetres to hundreds of kilometres (Cassie 1963, Fasham 1978, Mackas et al. 1985). The quantification of the spatial and temporal structure of phytoplankton distributions has nevertheless mainly focused on empirical observations at scales greater than $10 \mathrm{~m}$ to several kilometres (Platt 1972, Denman \& Platt 1976, Fasham \& Pugh 1976, Weber et al. 1986, Denman \& Abbott 1994, Strutton et al. 1997, Martin 2003). Theoretical and empirical studies have shown, however, that the analysis of large-scale (i.e. regional) patterns must integrate processes occurring at small (local) scales (Levin 1992).

Despite the long standing assumption that turbulence homogenises phytoplankton distribution at scales of $<1 \mathrm{~m}$, the existence of horizontal (e.g. Cassie 1963, Seuront et al. 1996, 1999, Waters et al. 2003) and vertical (e.g. McAlice 1970, Mitchell \& Fuhrman 1989, Cowles et al. 1993, Waters \& Mitchell 2002) patchiness in phytoplankton distributions, measured at scales of centimetres to tens of centimetres, has been widely reported, suggesting that microscale phytoplankton patchiness is a ubiquitous feature of the marine envi- ronment. Recent quantification of the horizontal spatial organisation of small-scale in vivo fluorescence distributions indicated that distributions were significantly statistically non-random (Seuront et al. 1999, Waters \& Mitchell 2002, Waters et al. 2003).

While much has been written about the effects of turbulence on marine ecosystems (Marrasé et al. 1997), no studies have specifically focused on the potential effects of different turbulence intensities and advective tidal processes on small-scale phytoplankton patchiness. Turbulence has recently been suggested as a potential driver of phytoplankton patchiness for scales ranging from tens of centimetres to tens of metres (Seuront \& Schmitt 2005). However, to my knowledge the potential links between small-scale phytoplankton patchiness and turbulence have never been thoroughly investigated. Similarly, periodical advections of water masses of different physical and biological properties are ubiquitous in tidally driven coastal ecosystems (e.g. Mann \& Lazier 1996), and can have salient effects on the structure and function of estuarine, coastal and intertidal environments. Nevertheless, no attention has previously been paid to the potential differential effects of these processes on small-scale phytoplankton patchiness. 
On the basis of high-frequency in vivo fluorescence time series recorded in a highly dissipative tidally mixed coastal ecosystem, the eastern English Channel, under significantly different tidal and turbulence conditions, the aim of this study was to demonstrate that the small-scale phytoplankton patchiness demonstrated in earlier studies (Seuront et al. 1996, 1999) is controlled by turbulence intensity and tidal advective processes. It is stressed that, because of the dissipative nature of the investigated water column, this study specifically relates to horizontal patchiness in an unstratified water column, and is therefore not relevant for the vertical phytoplankton variability in a stratified water column, which might result from buoyancy effects, vertical gradients of nutrients and/or the exponential light profile. The results indicate that phytoplankton patchiness increases with decreasing turbulence intensity and is always higher during flood tide for a given turbulence intensity, and are used to infer the dominance of potential physical and biological structuring mechanisms operating at small scales.

\section{MATERIALS AND METHODS}

Field site and sampling strategy. Sampling was conducted from 2 to 4 April 1996 at an anchor station (Fig. 1) in the coastal waters of the eastern English Channel $\left(50^{\circ} 47^{\prime} 300^{\prime \prime} \mathrm{N}, 1^{\circ} 33^{\prime} 500^{\prime \prime} \mathrm{E}\right)$ for $48 \mathrm{~h}(\sim 4$ tidal cycles) during the spring tide. The tidal range (between 3 and $9 \mathrm{~m}$ ) in this area is one of the largest in the world, and tides are characterised by a residual

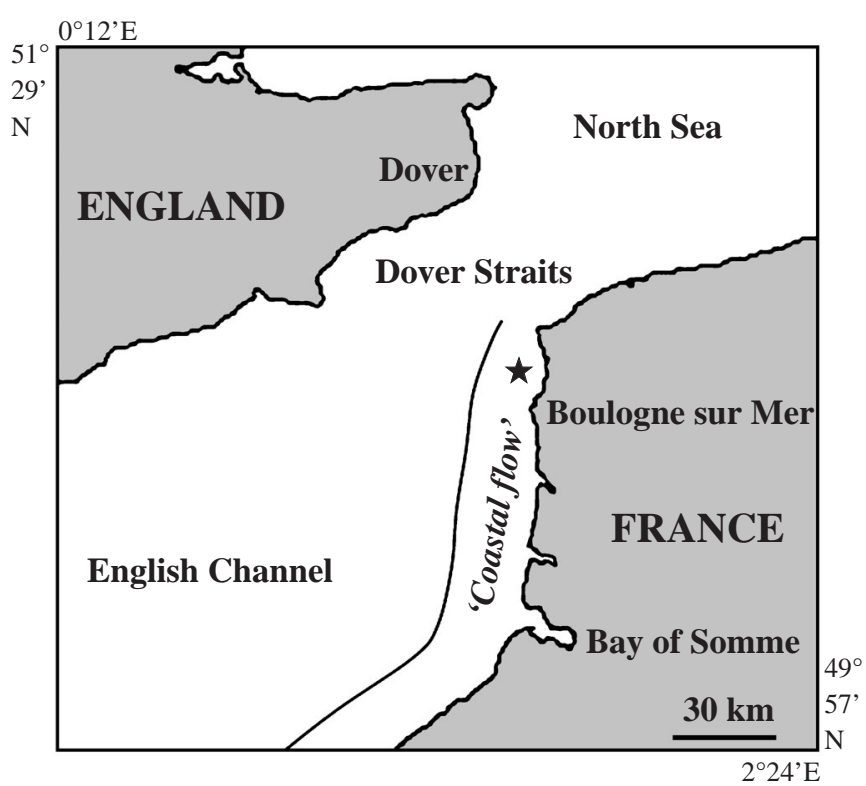

Fig. 1. Study area and location of sampling station off the French coast $(\star)$ of the eastern English Channel circulation parallel to the coast, with nearshore coastal waters drifting from the English Channel into the North Sea. Coastal waters, also referred to as a 'coastal flow' (Brylinski et al. 1991), are influenced by freshwater run-off from the Seine Estuary to the Straits of Dover, and separated from offshore waters by a transient, tidally controlled frontal area (Brylinski \& Lagadeuc 1990, Lagadeuc et al. 1997). The region is characterised by low salinity, turbidity (Dupont et al. 1991), phytoplankton richness (Brylinski et al. 1984) and high productivity (Brunet et al. 1992, 1993). More specifically, the sampling location was chosen because the physical and hydrological properties are representative of the coastal water flow encountered in the eastern English Channel (Brunet et al. 1992).

In a high-resolution time series at $2 \mathrm{~Hz}$, temperature and salinity (regarded as passive scalars under physical control) and in vivo fluorescence (a proxy for phytoplankton biomass) were measured simultaneously at a single depth $(10 \mathrm{~m})$ with a Sea-Bird Sealogger CTD probe and a SeaTech fluorometer, respectively. In addition, temperature and salinity and in vivo fluorescence were measured every hour from the surface to the bottom with a Sea-Bird 19 Sealogger CTD and a SeaTech fluorometer. Current speed and direction were measured every $5 \mathrm{~min}$ at 3, 6 and $10 \mathrm{~m}$ with Anderra current meters. Wind data were collected every hour with a shipboard anemometer. Water samples were collected every hour from a depth of $10 \mathrm{~m}$ with Niskin bottles, and chlorophyll a concentrations were estimated following Strickland \& Parsons (1972) from 1 l filtered frozen samples, extracted with $90 \%$ acetone, and assayed in a spectrophotometer.

Quantifying dissipation rate of kinetic energy of turbulence. In the eastern English Channel, the kinetic energy of turbulence can be generated by wind and/or tide. The dissipation rate of the kinetic energy of windgenerated turbulence $\varepsilon_{\mathrm{w}}\left(\mathrm{m}^{2} \mathrm{~s}^{-3}\right)$ was calculated using the formula for the boundary layer model used by MacKenzie \& Leggett (1991):

$$
\varepsilon_{\mathrm{w}}=\left(5.82 \times 10^{-9}\right) U^{3} / z
$$

where $U$ and $z$ are wind speed $\left(\mathrm{m} \mathrm{s}^{-1}\right)$ and sampling depth $(10 \mathrm{~m})$, respectively. The dissipation rate of turbulence energy induced by the tidal flow $\varepsilon_{\mathrm{t}}\left(\mathrm{m}^{2} \mathrm{~s}^{-3}\right)$ was subsequently estimated following MacKenzie \& Leggett (1993):

$$
\varepsilon_{\mathrm{t}}=\phi u^{3} / h
$$

where $\phi, u$ and $h$ are the fractions of tidal energy used for vertical mixing $(\phi=0.006$, Bowers \& Simpson 1987), the depth-averaged velocity of the tidal flow $\left(\mathrm{m} \mathrm{s}^{-1}\right)$ and the depth of the water column $(\mathrm{m})$, respectively. Values of $\varepsilon_{\mathrm{t}}$ exceeding $2.4 \times 10^{-5} \mathrm{~m}^{2} \mathrm{~s}^{-3}$ are typical of tidally mixed waters (MacKenzie \& Leggett 1991). 
The vertical stability of the water column cannot be estimated by Richardson number (Ri) or static stability $\left(N^{2}\right)$ because the water column has no vertical structure, i.e. no vertical gradient of density. Nevertheless, the dynamic stability of the water column was estimated using the square of the total shear $S$ (Itsweire et al. 1989):

$$
S^{2}=(\Delta u / \Delta z)^{2}+(\Delta v / \Delta z)^{2}
$$

where $\Delta z$ is variation in depth, and $\Delta u$ and $\Delta v$ are variations in the instantaneous speed of the 2 orthogonal components $u$ (cross-channel) and $v$ (along-channel) of the tidal current, respectively.

Quantifying phytoplankton patchiness. For fully developed homogeneous turbulence, power laws have been proposed for fluctuations in passive scalars (i.e. temperature, salinity, and a priori phytoplankton cells) in Fourier space (Obukhov 1949, Corrsin 1951) via power spectral analysis as $E(k) \propto f^{-\beta}$, where $f$ is frequency $\left(\mathrm{s}^{-1}\right)$ and $\beta \approx 5 / 3$. Strictly speaking, a spectral analysis corresponds to an analysis of variance in which the total variance of a given process is partitioned into contributions arising from processes with different time scales. A power spectrum then separates and measures the amount of variability occurring in different frequency bands. When all or parts of the spectrum follow the above mentioned power law, this indicates the absence of any characteristic time scale in the range of scales to which the power law applies.

However, power spectral analysis, implicitly based on Gaussian statistics and limited to a second-order statistic (the variance), characterises very poorly quantities that vary intermittently (i.e. occasional and unpredictable large peaks separated by very low values). A generalisation of the widely used power spectral approach in real space was thus adopted with the help of the $q$ th order structure functions that have been extensively described and illustrated elsewhere (Seuront et al. 1996, 1999, 2002). For a given quantity, $X$, fluctuating in time, the $q$ th order structure functions are defined as $\left\langle(\Delta X(\tau))^{q}\right\rangle \propto\left\langle|X(t+\tau)-X(\tau)|^{q}\right\rangle$, where the brackets ' $\langle$.$\rangle ' indicate an average performed for all$ points of the data set separated by a distance $\kappa$ and $q$ is the statistical order of moment (e.g. $q=1$ and $q=2$ for the mean and the variance). $\left\langle(\Delta X(\tau))^{q}\right\rangle$ is then the $q$ th order statistical moments of the fluctuations of the quantity $X$ at the time scale $\tau$. For scaling processes, the scale invariant exponents $\zeta(q)$ characterise all the statistics of the field and are defined as $\left\langle(\Delta X(\tau))^{q}\right\rangle \propto \tau^{\zeta(q)}$. The scaling exponents $\zeta(q)$ are estimated by the slope of the linear trends of $\left\langle(\Delta X(\tau))^{q}\right\rangle$ vs. $\tau$ in a log-log plot. In particular, the first moment gives the scaling exponent $\zeta(1)=H$, corresponding to the scale-dependency of the average fluctuations: if $H \neq 0$, the fluctuations will depend on the time scale. The second moment is linked to the power spectral slope $\beta$, as $\beta=1+\zeta(2)$. For scaling (i.e. fractal) processes, the function $\zeta(q)$ is linear: $\zeta(q)=q / 2$ for Brownian motion, and $\zeta(q)=q / 3$ for non-intermittent turbulence. For multiscaling (i.e. multifractal) processes, this function is non-linear and convex (Seuront et al. 1999). The convexity of the function $\zeta(q)$ expresses the intermittent (i.e. patchy) deviation from homogeneity, in which case $\zeta(q)=q H$. Practically speaking, the nonlinearity of the function $\zeta(q)$ characterises a heterogeneous distribution with a few dense patches over a wide range of low density patches, and will thus be used hereafter as an index of phytoplankton patchiness: the more convex $\zeta(q)$, the more patchy the phytoplankton distribution.

\section{RESULTS}

\section{Hydrodynamic conditions}

At all depths, current vectors showed wide variations, related to the semidiurnal (12.4 h) tidal component (Fig. 2A). During flood and ebb tide, offshore and inshore waters were consequently advected inshore and offshore, respectively. This resulted in variations of $6 \mathrm{~h}$ periodicity in the current speed, which ranged from 5 to $116 \mathrm{~cm} \mathrm{~s}^{-1}$ at 3,3 to $109 \mathrm{~cm} \mathrm{~s}^{-1}$ at $6 \mathrm{~m}$ and 2 to
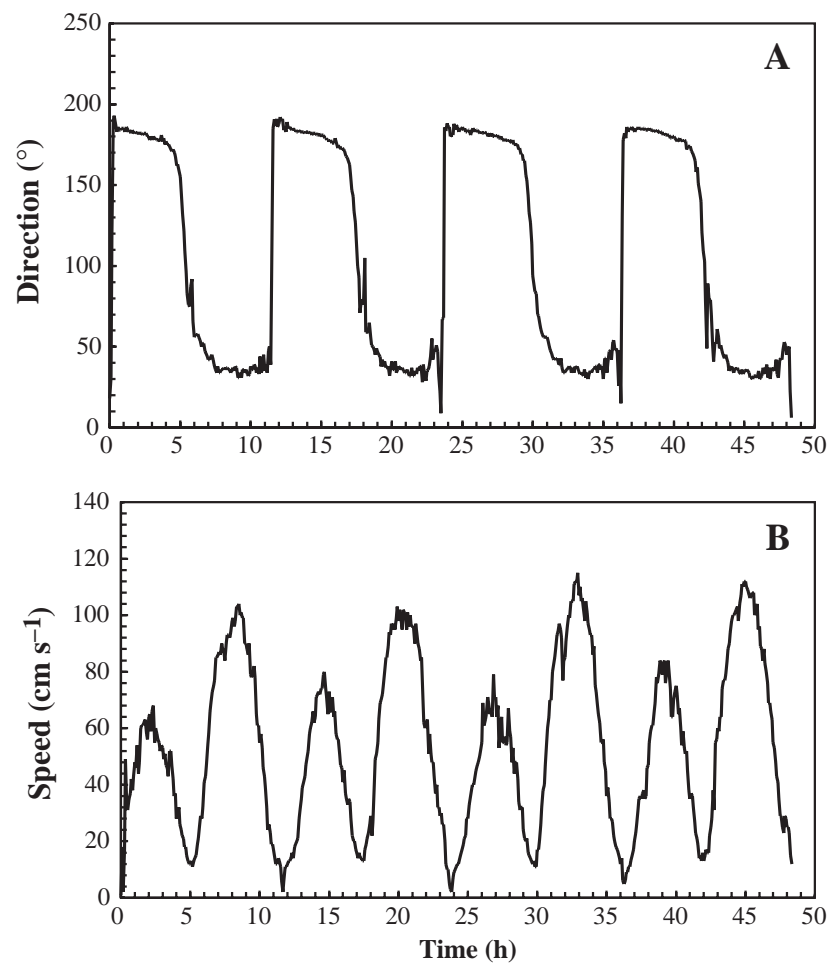

Fig. 2. Time series (5 min resolution) of (A) instantaneous tidal current direction and (B) speed during sampling experiment in the eastern English Channel 
$115 \mathrm{~cm} \mathrm{~s}^{-1}$ at $9 \mathrm{~m}$ depth (Fig. 2B). No significant differences were detected between current speed and direction at any of the 3 depths investigated (Kruskal-Wallis test, $\mathrm{p}<0.01)$. The related depth-averaged mean dissipation rates $\varepsilon_{\mathrm{t}}, \varepsilon_{\mathrm{t}}=6.85 \times 10^{-5} \mathrm{~m}^{2} \mathrm{~s}^{-3}$, ranged from $1.32 \times 10^{-7}$ to $3.07 \times 10^{-4} \mathrm{~m}^{2} \mathrm{~s}^{-3}$, which is characteristic of a strongly mixed tidal area. The vertical shear activity $S^{2}\left(S^{2}=8.32 \times 10^{-3} \mathrm{~s}^{-2}\right)$, which can generate turbulence, was always higher than $2.4 \times 10^{-4} \mathrm{~s}^{-2}$, a low shear effect according to Itsweire et al. (1989), indicating an elevated turbulence in the water column. The moderate NNE wind $\left(3.9 \pm 0.4 \mathrm{~m} \mathrm{~s}^{-1} ; \bar{x} \pm \mathrm{SD}\right)$ that blew during the sampling experiment induced dissipation rates $\varepsilon_{\mathrm{w}}$ ranging from $1.57 \times 10^{-8}$ to $5.30 \times 10^{-8}$. These low dissipation rates indicated a negligible effect of the kinetic energy of wind-induced turbulence on the water column, especially when compared to the dissipation rate induced by the tidal flow. Autocorrelation and cross-correlation analyses showed that salinity also varied with a periodicity of $12 \mathrm{~h}$, and was negatively correlated with current direction $(p<0.05)$. Temperature exhibited a significantly autocorrelated $12 \mathrm{~h}$ tidal cycle, with a superimposed diel cycle (sinusoidal regression, $r^{2}=0.68$ ).

\section{Phytoplankton biomass}

The chlorophyll a concentration was $14.4 \pm 4.80 \mu \mathrm{g}$ $\mathrm{l}^{-1}(\bar{x} \pm \mathrm{SD})$, which is in the range of values encountered in the eastern English Channel during the spring phytoplankton bloom period (Seuront et al. 1999). No decrease in in vivo fluorescence was observed in the surface layers or at the sampling depth during the daylight period, indicating the absence of photoinhibition (Falkowski \& Kiefer 1985). In addition, as chlorophyll a concentrations appear to be significantly correlated with in vivo fluorescence (Kendall's $\tau, \mathrm{p}<0.01$ ), the high-frequency in vivo fluorescence data recorded in the present study can be regarded as a direct and reliable estimate of phytoplankton biomass. Autocorrelation analysis of chlorophyll a identified a significant $(p<0.05) 12 \mathrm{~h}$ tidal cycle in chlorophyll a concentrations. In addition, cross-correlation analysis between current direction and chlorophyll a showed that phytoplankton biomass was positively correlated $(p<0.05)$ with tidal current direction.

\section{Subsampling of phytoplankton populations}

A direct consequence of the advective processes detailed above is that during a full tidal cycle, inshore and offshore waters would flow past the stationary sampling site during an ebb and a flood period. It is thus impossible to separate inshore and offshore effects by dividing the sampling into ebb and flood periods, as both water types would be sampled during the first and second half of each period, respectively. To separate the inshore from the offshore waters, the subsampling periods were shifted relative to the tidal phase by half the tidal period (i.e. $3 \mathrm{~h}$ ). Offshore waters were sampled during the second half of the flood tide, while inshore waters were sampled during the second half of the ebb tide. The first half of both flood and ebb tides was investigated separately to infer any potential differences in phytoplankton patchiness of inshore and offshore waters related to the flood tide/ebb tide transition. Twenty four time series (30 min duration) of in vivo fluorescence were analyzed during the first and second half of the flood and ebb tides. For comparison, and to provide a reference framework that can be related to purely passive scalars, the original temperature and salinity time series were also subsampled. The dissipation rates $\varepsilon_{\mathrm{t}}$ estimated during the first and second halves of both flood and ebb tide were very similar (Fig. 3). They ranged from $1.54 \times 10^{-7}$ to $2.55 \times$ $10^{-4}$ and $1.91 \times 10^{-7}$ to $3.06 \times 10^{-4} \mathrm{~m}^{2} \mathrm{~s}^{-3}$ for the first half of the flood and ebb tides, and from $2.60 \times 10^{-7}$ to $2.98 \times$ $10^{-4}$ and $5.07 \times 10^{-7}$ to $3.52 \times 10^{-4} \mathrm{~m}^{2} \mathrm{~s}^{-3}$ for the second half of the flood and ebb tides, respectively. Analysis of these data subsets allows direct comparisons of the effect of turbulence on patchiness of inshore and offshore phytoplankton populations.

\section{Turbulence, tide and phytoplankton patchiness}

The function $\zeta(q)$ was estimated from the linear behaviour of the in vivo fluorescence structure functions, $\left\langle(\Delta F(\tau))^{q}\right\rangle$, as a function of the time scale $\tau$ in a log-log plot for values of $q$ ranging from 0.1 to 5, with 0.05 increments (Fig. 4). It must be noted here that because the data sets considered are time series, the time scales $\tau$ were converted into length scales 1 . This was achieved using the mean instantaneous tidal current speed $V$ measured at the sampling depth during the recording process of each time series, considered here as $l=V \times \tau$. A power law behaviour was observed for time scales ranging from 1 to $19.85 \pm 1.13 \mathrm{~s}\left(\bar{X} \pm \mathrm{SD}_{\text {; }}\right.$ $x \in$ [18.04 to 21.93]) for in vivo fluorescence (Fig. 4), and from 1 to $1002.32 \pm 29.24 \mathrm{~s}(\bar{x} \pm \mathrm{SD} ; x \in[950.52$ to 1049.19]) for temperature and salinity (data not shown). The related spatial scales then range from $0.28 \pm$ $0.16 \mathrm{~m}(\bar{x} \pm \mathrm{SD} ; x \in[0.05-0.53])$ to $11.03 \pm 6.19 \mathrm{~m}$ $\left(\bar{x} \pm \mathrm{SD}_{i} \bar{x} \in[1.81\right.$ to 21.88]) for in vivo fluorescence, and from $0.28 \pm 0.16 \mathrm{~m}\left(\bar{x} \pm \mathrm{SD}_{i} x \in[0.05\right.$ to 0.53$\left.]\right)$ to $559.07 \pm 313.82 \mathrm{~m}(\bar{x} \pm \mathrm{SD} ; x \in$ [90.19 to 1099.69]) for temperature and salinity. The results of the patchiness analysis of the in vivo fluorescence time series are 


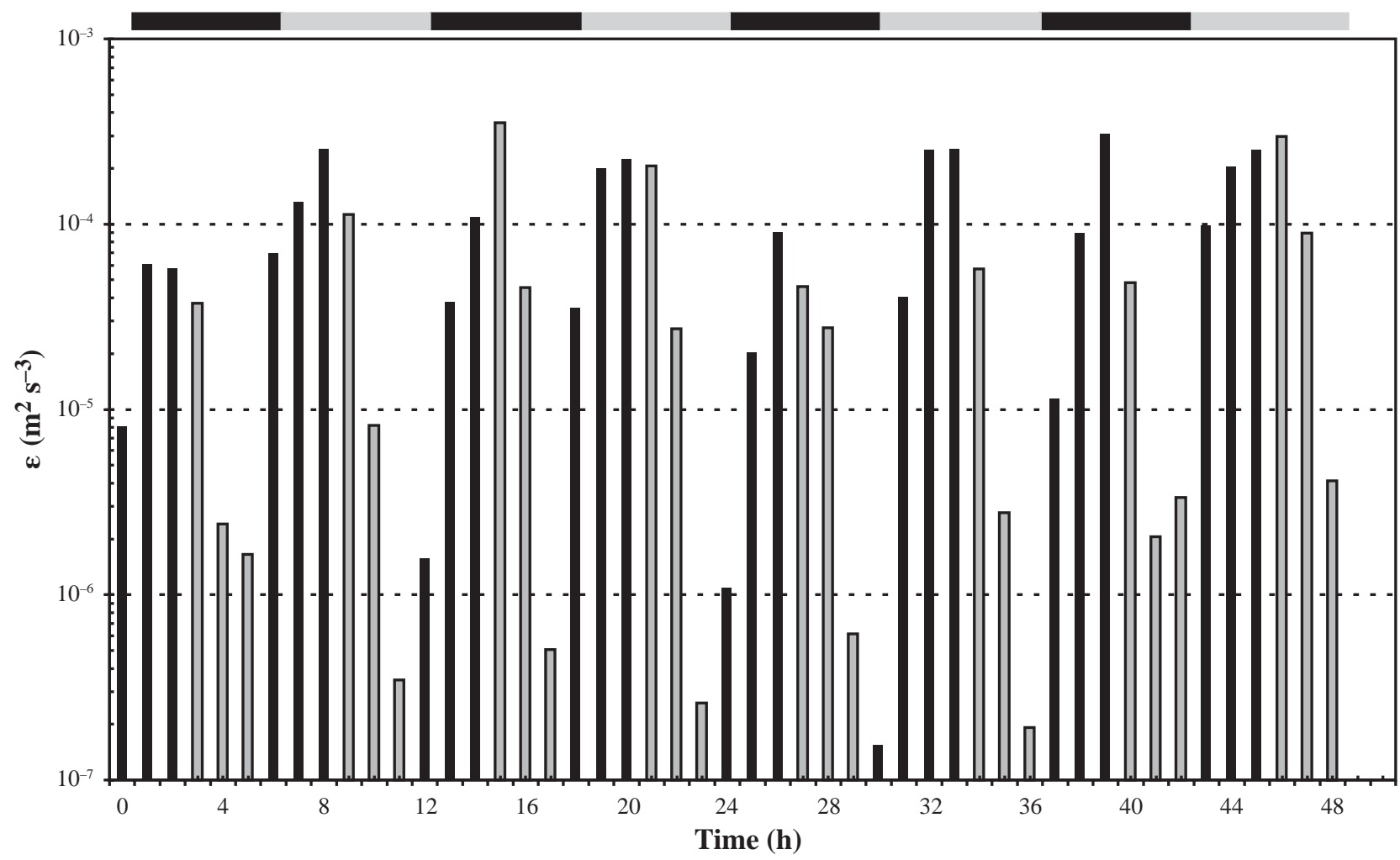

Fig. 3. Time series of dissipation rates of tidally induced turbulence $\left(\varepsilon_{t}\right)$ investigated in framework of phytoplankton patchiness study. Black and grey vertical bars: subsampling during first and second half of each tidal period, respectively; black and grey horizontal bars on top abscissa: ebb and flood tide conditions, respectively

shown in Fig. 4. The clear nonlinearity of the function $\zeta(q)$ illustrates the patchy character of small-scale phytoplankton distributions (Fig. 5).

The function $\zeta(q)$ estimated for the temperature and salinity time series remained the same across variable turbulence and tidal conditions (Figs. 5 \& 6). In contrast, for a given turbulence level, phytoplankton biomass was always more patchy during the second half of ebb tide than during the second half of flood tide (Fig. 5), suggesting more patchiness in inshore than in offshore waters. More specifically, the difference between the function $\zeta(q)$ estimated during flood tide (Fig. 6A) and ebb tide (Fig. 6B) indicates that for the same range of turbulence intensities phytoplankton patchiness decreased during the flood tide (Fig. 6A) and increases during the ebb tide (Fig. 6B). In addition, phytoplankton patchiness was higher at the beginning of the ebb tide than at the beginning of the flood tide (Fig. 6). This is indicative of mixing between inshore and offshore water masses during the transition between flood and ebb tide. Flood and ebb tide phytoplankton populations can nevertheless exhibit very similar levels of patchiness (e.g. for the highest and lowest turbulence conditions considered for flood and ebb tides, respectively in Fig. 5). Finally, phytoplankton distributions were more and less patchy than would be a purely passive scalar in ebb and flood tide conditions, respectively. The gradients observed in the phytoplankton concentrations were thus higher and lower than temperature and salinity gradients in ebb and flood tide conditions, respectively, whatever the intensity of turbulence. As a consequence, inshore and off-

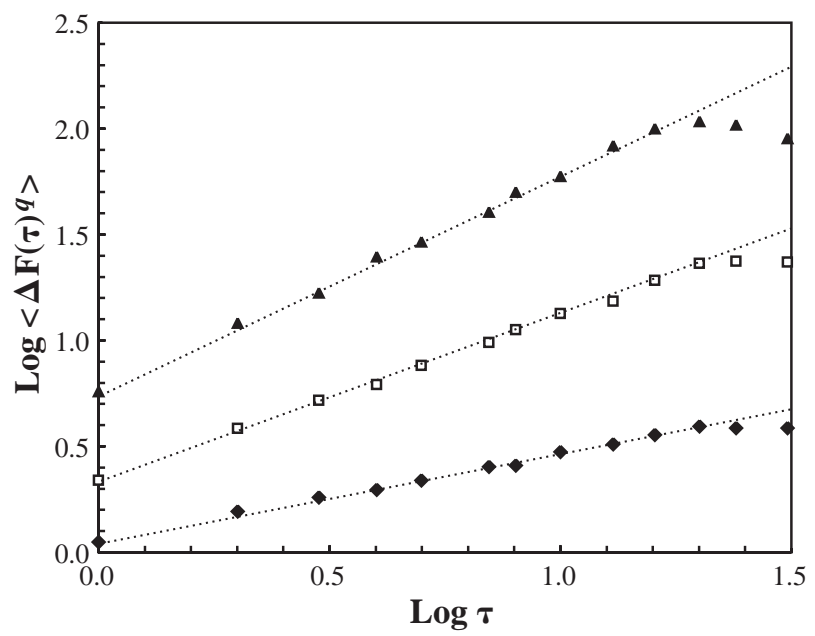

Fig. 4. In vivo fluorescence structure functions $\left\langle(\Delta F(\tau))^{q}\right\rangle$ vs. time scale $\tau$ in log-log plot for $q=1,2$ and 3 (from bottom to top), where slopes of lines provide estimates of first, second and third moment scaling exponent $\zeta$ 


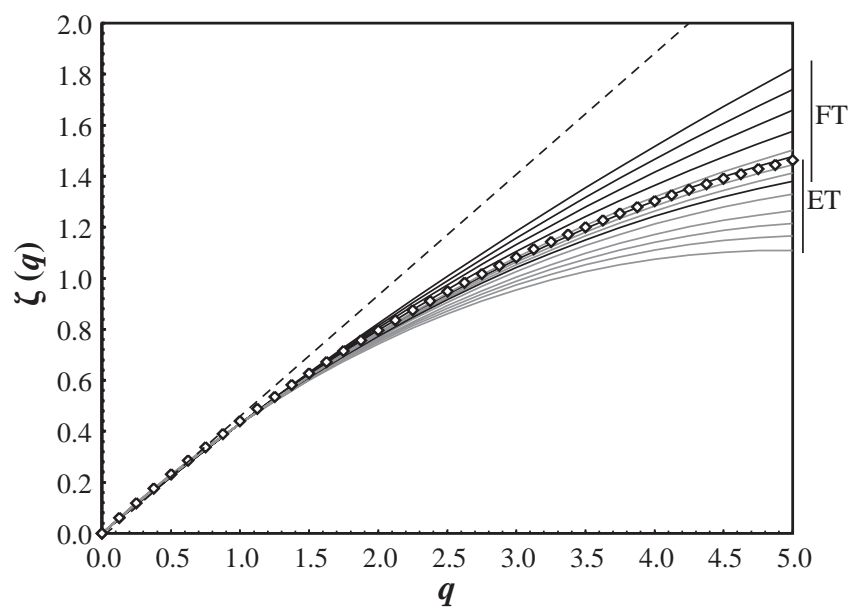

Fig. 5. Empirical scaling function $\zeta(q)$ estimated for in vivo fluorescence during second half of flood tide (FT; black lines) and ebb tide (ET; grey lines), compared to statistically indistinguishable empirical exponents estimated for temperature and salinity $(\diamond)$ and theoretical homogeneous linearity $\zeta(q)=$ $q H$ (dashed line). Nonlinearity of $\zeta(q)$ indicates that phytoplankton distributions are far from homogeneous, and that in both tidal conditions patchiness increases with decreasing dissipation of turbulence energy. Energy dissipation rates (from bottom to top) during ebb tide $=5.07 \times 10^{-7}, 1.11 \times 10^{-6}$, $5.17 \times 10^{-6}, 1.43 \times 10^{-5}, 5.13 \times 10^{-5}$ and $3.52 \times 10^{-4} \mathrm{~m}^{2} \mathrm{~s}^{-3}$, and during flood tide $=2.60 \times 10^{-7}, 4.70 \times 10^{-7}, 1.07 \times 10^{-6}, 5.16 \times$ $10^{-6}, 1.24 \times 10^{-5}, 6.32 \times 10^{-5}, 1.05 \times 10^{-4}$ and $2.98 \times 10^{-4} \mathrm{~m}^{2} \mathrm{~s}^{-3}$

shore phytoplankton populations must be respectively considered as more and less homogeneously distributed than purely passive scalars. This is indicative of the predominant influence of the biological properties of phytoplankton cells on turbulence processes. There is still no clear explanation as to why phytoplankton cells are more homogeneously distributed than a purely passive scalar during flood tide. However, this could be the result of biological properties such as the cohesiveness of Phaeocystis globosa cells/colonies, which is likely to dampen the gradients expected under the purely physical control of turbulence fluctuations.

\section{DISCUSSION}

\section{Biophysical sources of small-scale phytoplankton patchiness}

During spring blooms, the prymnesiophycean Phaeocystis globosa dominates the phytoplankton community in the eastern English Channel, especially in inshore waters (Seuront et al. 2002), and reached very high concentrations during the sampling period (Seuront \& Souissi 2002). The genus Phaeocystis, known
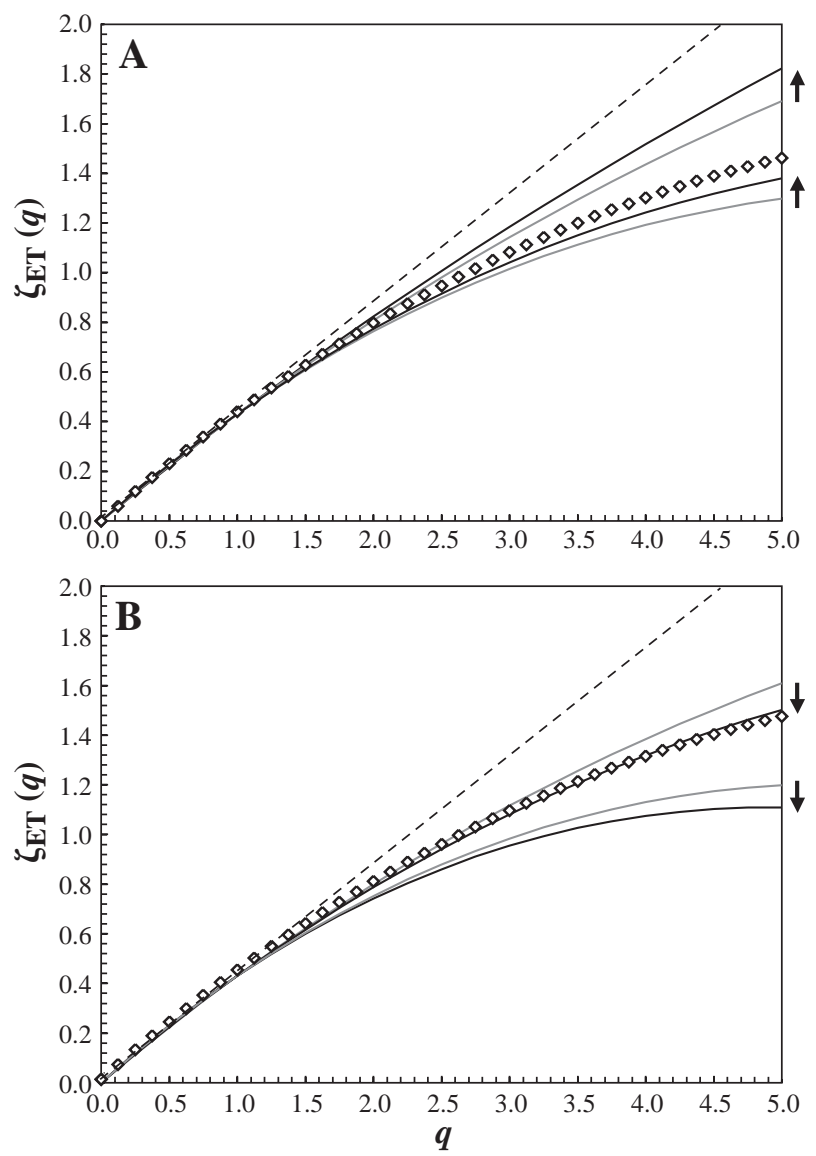

Fig. 6. Empirical scaling function $\zeta(q)$ estimated for in vivo fluorescence during first and second half of (A) flood and (B) ebb tide over same range of turbulence intensities. During first and second halves of flood tide, dissipation rates ranged (from bottom to top) from $1.54 \times 10^{-7}$ to $2.55 \times 10^{-4} \mathrm{~m}^{2} \mathrm{~s}^{-3}$ (grey lines) and from $2.60 \times 10^{-7}$ to $2.98 \times 10^{-4} \mathrm{~m}^{2} \mathrm{~s}^{-3}$ (black lines), respectively; during first and second halves of ebb tide, dissipation rates ranged (from bottom to top) from $1.91 \times 10^{-7}$ to $3.06 \times 10^{-4} \mathrm{~m}^{2} \mathrm{~s}^{-3}$ (grey lines) and from $5.07 \times 10^{-7}$ to $3.52 \times$ $10^{-4} \mathrm{~m}^{2} \mathrm{~s}^{-3}$ (black lines), respectively. Statistically indistinguishable empirical exponents estimated for temperature and salinity $(\diamond)$ and theoretical homogeneous linearity $\zeta(q)=q H$ (dashed lines) are shown for comparison; vertical arrows indicate shift in phytoplankton patchiness between first and second half of flood and ebb tides

for its highly developed swarming capacity (Verity \& Medlin 2003), is likely to be responsible for a high patchiness in inshore waters, especially over the smallest scales investigated here (ca. $20 \mathrm{~cm}$ ). Density of $P$. globosa (especially the colonial form) is much higher inshore than offshore (Seuront \& Souissi 2002). Coagulation processes involving large (i.e. $>1 \mathrm{~mm}$ ) P. globosa colonies could thus also contribute to increasing the level of phytoplankton patchiness observed inshore, especially in comparison with offshore waters dominated by the non-colonial genus Emiliana (Brylinski et al. 1991). Other biologically driven processes 
such as surface accumulations of ultraplankton caused by the low sinking rate of small cells (Raimbault et al. 1989) or of flagellates arising from their active displacement in the upper layer (Kamykowski et al. 1997), or the fast sinking of senescent $P$. globosa colonies (Peperzak et al. 2003) cannot be regarded as potential sources of patchiness because of the absence of any vertical trend in the fluorescence vertical profiles (Kendall's $\tau, p>0.05$ ).

Alternatively, while the formation of phytoplankton patches by near-inertial wave shear (Franks 1995) is unlikely to occur in the well-mixed coastal waters investigated here, other physical processes could be involved in the creation of phytoplankton patchiness. In particular, the influence of a tidal front, previously identified in a global analysis of the same data set (Seuront et al. 1999) and separating the inshore 'coastal flow' from offshore waters, may be a major source of patchiness. The accumulation of phytoplankton biomass at fronts (e.g. Franks 1992), combined with horizontal tidal and wind-driven transport and/or shedding of eddies by instability of the tidal front, could create patchiness on horizontal scales in the order of $10 \mathrm{~km}$ (Franks \& Walstad 1997). Tidal and wind-driven alongshore transport and the northward spread of local blooms initiated in the Somme and Seine estuaries is also likely to be responsible for phytoplankton patchiness on a scale of kilometres (Ellien et al. 2004). Such large-scale phytoplankton patchiness is much larger than that observed herein, which lay between 0.3 and $11 \mathrm{~m}$. However, taking into account the depth of the water column and the turbulence dissipation rates in the present study (21 to $28 \mathrm{~m}$ and $10^{-7}$ to $10^{-4} \mathrm{~m}^{2} \mathrm{~s}^{-3}$, respectively), the large horizontal patches would be expected to cascade down to scales $<21$ to $28 \mathrm{~m}$ by the action of 3-dimensional and isotropic turbulence. Tidal mixing is also known to generate heterogeneity in suspended matter and phytoplankton throughout the water column (Eisma \& Li 1993, Blanchard et al. 2001), mainly through resuspension of benthic and tychoplanktonic phytoplankton populations, which particularly important in the inshore waters of the eastern English Channel (Dupont et al. 1991, Huault et al. 1994).

\section{Small-scale phytoplankton patchiness and zooplankton grazing}

Prey distribution is very important to predators, since food availability changes with level of patchiness. A patchy distribution means a smooth and predictable distribution of particles gathered in small numbers of patches, while a more homogeneous distribution means a rough, fragmented, compact and less pre- dictable distribution. When a predator can detect its prey at long distances, patchy prey distribution would be more advantageous. In contrast, when a predator has no such ability, homogeneous prey distributions would be more advantageous, since food quantity and thus encounter rate become proportional to the searched volume as patchiness decreases. In the present study, at similar turbulence intensities phytoplankton patchiness was always significantly higher inshore than offshore. This may explain why calanoid copepods such as Temora longicornis are much more abundant inshore than offshore in the eastern English Channel (e.g. Seuront \& Lagadeuc 2001), and display maximum abundance during a Phaeocystis sp. bloom (Fransz et al. 1992), since foraging would be much more profitable inshore than offshore.

Following the seminal work of Rothschild \& Osborn (1988), who proposed an enhanced rate of predatorprey contact due to microscale turbulence, subsequent studies have found both enhanced and depressed ingestion by copepods under turbulent conditions (e.g. Saiz \& Kiørboe 1995, Saiz et al. 2003). In the present work, increasing turbulence decreased phytoplankton patchiness in inshore and offshore waters (see Figs. 5 \& 6). Therefore, considering that predator-prey encounter rates are mainly driven by behavioural adaptation to prey patchiness (Seuront et al. 2001), increased turbulence may lead to lower food availability for copepods inshore than offshore.

The high chlorophyll a concentrations (14.41 \pm $4.80 \mathrm{\mu g} \mathrm{l}^{-1}$ ) in the present study were above the saturation threshold for feeding in Temora longicornis (Berggreen et al. 1988) assuming a C:chlorophyll $a$ ratio of 30:50. Thus, $T$. longicornis was not food limited and the effects of patchiness and turbulence would be negligible. However, several studies have shown that $T$. longicornis do not feed on solitary Phaeocystis spp. cells, even when these are available in high concentrations (Verity \& Smayda 1989, Hansen \& van Boekel 1991, Bautista et al. 1992, Breton et al. 1999). Other studies have shown that copepods do graze on Phaeocystis sp., but classified this alga as a poor food source (Cotonnec et al. 2001, Turner et al. 2002). On the other hand, Hamm \& Rousseau (2003) showed that colonies of P. globosa contain fatty acids of high nutritional value and are the major food source for copepods and decapods during P. globosa blooms. During the colonial phase of a P. globosa bloom, diatoms embedded in the colonies are grazed even at low concentrations (Van Rijswijk et al. 1989). I thus suggest that the phytoplankton observed herein might indirectly benefit $T$. longicornis, which preferentially grazes on diatoms and P. globosa colonies during the spring phytoplankton bloom, as recently shown by Devreker et al. (2005). 


\section{CONCLUSION}

This study provides support for the long-standing assumption that small-scale turbulence homogenises phytoplankton distributions, since phytoplankton patchiness decreased with increasing turbulence turbulence intensities ranging from $10^{-7}$ to $10^{-4} \mathrm{~m}^{2} \mathrm{~s}^{-3}$. In addition, phytoplankton patchiness was higher in inshore than in offshore waters and during ebb tide than flood tide in similar conditions of turbulence. Thus, because of the positively skewed trends of the distributions (see also Seuront et al. 1999, 2002), phytoplankton stocks are likely to be systematically underestimated because of the intrinsic patchy properties of the phytoplankton populations. More specifically, in the eastern English Channel, this bias would be higher for inshore than offshore phytoplankton populations, and would decrease with increasing turbulence intensity. This study has demonstrated that the phenomenon of small-scale phytoplankton patchiness emphasizes the need for detailed investigation of biological space-time structure and biophysical interactions at ecologically relevant scales.

Acknowledgements. I acknowledge the captain and the crew of the NO 'Côte d'Aquitaine' for their help during sampling. $\mathrm{R}$. Waters is gratefully acknowledged for her constructive discussions, as well as for improving the language. This work was supported financially and infrastructurally by the Centre National de la Recherche Scientifique, Université des Sciences et Technologies de Lille, Australian Research Council and Flinders University.

\section{LITERATURE CITED}

Bautista B, Harris RP, Tranter PR, Harbour D (1992) In situ copepod feeding and grazing rates during a spring bloom dominated by Phaeocystis sp. in the English Channel. J Plankton Res 14:691-703

Berggreen U, Hansen B, Kiørboe T (1988) Food size spectra ingestion and growth of the copepod Acartia tonsa during development: implications for determination of copepod production. Mar Biol 99:341-352

Blanchard GF, Guarini JM, Orvain F, Sauriau PG (2001) Dynamic behaviour of benthic microalgal biomass in intertidal mudflats. J Exp Mar Biol Ecol 264:85-100

Bowers DG, Simpson JH (1987) Mean position of tidal fronts in European-shelf seas. Cont Shelf Res 7:35-44

Breton E, Sautour B, Brylinski JM (1999) No feeding on Phaeocystis sp. as solitary cells (post-bloom period) by the copepod Temora longicornis in the coastal waters of the English Channel. Hydrobiologia 414:13-23

Brunet C, Brylinski JM, Degros N, Hilde D (1992) Productivity, photosynthetic pigments and hydrology in the coastal front of the Eastern English Channel. J Plankton Res 14: 1541-1552

Brunet C, Brylinski JM, Lemoine Y (1993) In situ variations of the xanthophylls dioxanthin and diadinoxanthin: photoadaptation and relationships with a hydrodynamical system in the eastern English Channel. Mar Ecol Prog Ser 102: $69-77$
Brylinski JM, Lagadeuc Y (1990) L'interface eau côtière/eau du large dans le Pas-de-Calais (côte française): une zone frontale. CR Acad Sci Paris Sér II 311:535-540

Brylinski JM, Dupont J, Bentley D (1984) Conditions hydrologiques au large du cap Griz-Nez (France): premiers résultats. Oceanol Acta 7:315-322

Brylinski JM, Lagadeuc Y, Gentilhomme V, Dupont JP and 7 others (1991) Le 'fleuve côtier': un phénomène hydrologique important en Manche orientale. Exemple du Pasde-Calais. Oceanol Acta 11:197-203

Cassie RM (1963) Microdistribution in the plankton. Oceanogr Mar Biol Annu Rev 1:223-252

Corrsin S (1951) On the spectrum of isotropic temperature in an isotropic turbulence. J Appl Physiol 22:469

Cotonnec G, Brunet C, Sautour B, Thoumelin G (2001) Nutritive value and selection of food particles by copepods during a spring bloom of Phaeocystis sp. in the English Channel, as determined by pigment and fatty acid analyses. J Plankton Res 23:693-703

Cowles TJ, Desiderio RA, Neuer WS (1993) In situ characterisation of phytoplankton from vertical profiles of fluorescence spectra. Mar Biol 115:217-222

Denman KL, Abbott MA (1994) Time scales of pattern evolution from cross-spectrum analysis of advanced very high resolution radiometer and coastal zone color scanner imagery. J Geophys Res 99:7433-7442

Denman KL, Platt T (1976) The variance spectrum of phytoplankton in a turbulent ocean. J Mar Res 34:593-601

Devreker D, Souissi S, Seuront L (2005) Effects of chlorophyll concentration and temperature variation on the reproduction and survival of Temora longicornis (Copepoda, Calanoida) in the Eastern English Channel. J Exp Mar Biol Ecol 318:145-162

Dupont JP, Lafite R, Huault MF, Lamboy M, Brylinski JM, Guéguéniat P (1991) La dynamique des masses d'eau et matière en suspension en Manche orientale. Oceanol Acta 11:177-186

Eisma D, Li A (1993) Changes in suspended matter floc size during the tidal cycle in the Dollar Estuary. Neth J Sea Res 31:107-117

Ellien C, Thiebaut E, Dumas F, Salomon JC, Nival P (2004) A modelling study of the respective role of hydrodynamic processes and larval mortality on larval dispersal and recruitment of benthic invertebrates: example of Pectinaria koreni (Annelida: Polychaeta) in the Bay of Seine (English Channel). J Plankton Res 26:117-132

Falkowski PG, Kiefer DA (1985) Chlorophyll a fluorescence in phytoplankton: a comparative field study. J Mar Res 7: 715-731

Fasham MJR (1978) The statistical and mathematical analysis of plankton patchiness. Oceanogr Mar Biol Annu Rev 16: 43-79

Fasham MJR, Pugh PR (1976) Observations on the horizontal coherence of chlorophyll $a$ and temperature. Deep-Sea Res 23:527-538

Franks PJS (1992) Sink or swim: acumulation of biomass at fronts. Mar Ecol Prog Ser 82:1-12

Franks PJS (1995) Thin layers of phytoplankton: a model of formation by near-inertial wave shear. Deep-Sea Res I 42: 75-91

Franks PJS, Walstad LJ (1997) Phytoplankton patches at fronts: a model of formation and response to wind events. J Mar Res 55:1-29

Fransz HG, Gonzalez SR, Cadée GC, Hansen FC (1992) Longterm change of Temora longicornis (Copepoda, Calanoida) abundance in a Dutch tidal inlet (Marsdiep) in relation to eutrophication. Neth J Sea Res 30:23-32 
Hamm CE, Rousseau V (2003) Composition, assimilation and degradation of Phaeocystis globosa-derived fatty acids in the North Sea. J Sea Res 50:271-283

Hansen BW, van Boekel WHM (1991) Grazing pressure of the calanoid copepod Temora longicornis on a Phaeocystis dominated spring bloom in a Dutch tidal inlet. Mar Ecol Prog Ser 78:123-129

Huault MF, Lafite R, Dupont JP (1994) Diatoms as particulate tracers in the water column in the Eastern English Channel. Neth J Sea Res 33:47-56

Itsweire EC, Osborn TR, Stanton TP (1989) Horizontal distribution and characteristics of shear layers in the seasonal thermocline. J Phys Oceanogr 10:301-320

Kamykowski D, Yamazaki H, Yamazaki AK, Kirkpatrick G (1997) A comparison of how different orientation behaviours influence dinoflagellate trajectories and photoresponses in turbulent water columns. In: Anderson DM, Cambella AD, Hallegraeff GM (eds) The physical ecology of harmful algal blooms. Springer-Verlag, Berlin, p 581-599

Lagadeuc Y, Brylinski JM, Aelbrecht D (1997) Temporal variability of the vertical stratification of a front in a tidal region of freshwater influence (ROFI) system. J Mar Res 12: 147-155

Levin SA (1992) The problem of patterns and scale in ecology. Ecology 73:1943-1967

Mackas DL, Denman KL, Abbott MR (1985) Plankton patchiness: biology in the physical vernacular. Bull Mar Sci 37: 652-674

MacKenzie BR, Leggett WC (1991) Quantifying the contribution of small-scale turbulence to the encounter rates between larval fish and their zooplankton prey: effects of wind and tide. Mar Ecol Prog Ser 73:149-160

MacKenzie BR, Leggett WC (1993) Wind-based models for estimating the dissipation rates of turbulence energy in aquatic environments: empirical comparisons. Mar Ecol Prog Ser 94:207-216

Mann KH, Lazier JRN (1996) Dynamics of marine ecosystems. Blackwell, Boston, MA

Marrasé C, Saiz E, Redondo JM (1997) Lectures on plankton and turbulence. Sci Mar 61:1-238

Martin AP (2003) Phytoplankton patchiness: the role of lateral stirring and mixing. Prog Oceanogr 57:125-174

McAlice BJ (1970) Observations on the small-scale distributions of estuarine phytoplankton. Mar Biol 7:100-111

Mitchell JG, Fuhrman JA (1989) Centimeter scale vertical heterogeneity in bacteria and chlorophyll a. Mar Ecol Prog Ser 54:141-148

Obukhov AM (1949) Structure of the temperature field in a turbulent flow. Izv Akad Nauk SSSR Ser Geogr Geofiz 13:55

Peperzak L, Colinj F, Koeman R, Gieskes WWC, Joordens JCA (2003) Phytoplankton sinking rates in the Rhine region of freshwater influence. J Plankton Res 25:365-383

Platt T (1972) Local phytoplankton abundance and turbulence. Deep-Sea Res 19:183-187

Raimbault P, Taupier-Lepage I, Rodier M (1989) Vertical size distribution of phytoplankton in the western Mediterranean Sea during early summer. Mar Ecol Prog Ser 45:153-158

Rothschild BJ, Osborn TR (1988) Small-scale turbulence and plankton contact rates. J Plankton Res 10:465-474

Saiz E, Kiørboe T (1995) Predatory and suspension feeding of

Editorial responsibility: Otto Kinne (Editor-in-Chief),

Oldendorf/Luhe, Germany the copepod Acartia tonsa in turbulent environments. Mar Ecol Prog Ser 122:147-158

Saiz E, Calbet A, Broglio E (2003) Effects of small-scale turbulence on copepods: the case of Oithona davisae. Limnol Oceanogr 48:1304-1311

Seuront L, Lagadeuc Y (2001) Multiscale patchiness of the calanoid copepod Temora longicornis in a turbulent coastal sea. J Plankton Res 23:1137-1145

Seuront L, Schmitt F (2005) Multiscaling statistical procedures for the exploration of biophysical couplings in intermittent turbulence. Part II. Applications. Deep-Sea Res II (in press)

Seuront L, Souissi S (2002) Evidence for climatic control of Phaeocystis sp. bloom in the Eastern English Channel. Mer 40:41-51

Seuront L, Schmitt F, Lagadeuc Y, Schertzer D, Lovejoy S, Frontier S (1996) Multifractal analysis of phytoplankton biomass and temperature in the ocean. Geophys Res Lett 23:3591-3594

Seuront L, Schmitt F, Lagadeuc Y, Schertzer D, Lovejoy S (1999) Multifractal analysis as a tool to characterize multiscale inhomogeneous patterns. Example of phytoplankton distribution in turbulent coastal waters. J Plankton Res 21: 877-922

Seuront L, Schmitt F, Lagadeuc Y (2001) Turbulence intermittency, small-scale phytoplankton patchiness and encounter rates in plankton: where do we go from here? Deep-Sea Res I 48:1199-1215

Seuront L, Gentilhomme V, Lagadeuc Y (2002) Small-scale nutrient patches in tidally mixed coastal waters. Mar Ecol Prog Ser 232:29-44

Strickland JDH, Parsons TR (1972) A practical handbook of seawater analysis, 2nd edn. Bull Fish Res Bd Can 167:1-310

Strutton PG, Mitchell JG, Parslow JS, Greene RM (1997) Phytoplankton patchiness: quantifying the biological contribution using fast repetition rate fluorometry. J Plankton Res 19:1265-1274

Turner JT, Ianora A, Esposito F, Carotenuto Y, Miralto A (2002) Zooplankton feeding ecology: does a diet of Phaeocystis support good copepod grazing, survival, egg production and egg hatching success? J Plankton Res 24:1185-1195

Van Rijswijk P, Bakker C, Vink M (1989) Daily fecundity of Temora longicornis (Copepoda Calanoida) in the Oosterschelde estuary (SW Netherlands). Neth J Sea Res 23: 293-303

Verity PG, Medlin LK (2003) Observations on colony formation by the cosmopolitan phytoplankton genus Phaeocystis. J Mar Syst 43:153-164

Verity PG, Smayda TJ (1989) Nutritional value of Phaeocystis pouchetii (Prymnesiophyceae) and other phytoplankton for Acartia spp. (Copepoda): ingestion, egg production, and growth of nauplii. Mar Biol 100:161-171

Waters RL, Mitchell JG (2002) The centimetre-scale spatial structure of estuarine in vivo fluorescence profiles. Mar Ecol Prog Ser 237:51-63

Waters RL, Mitchell JG, Seymour JR (2003) Geostatistical characterisation of centimetre-scale spatial stucture of in vivo fluorescence. Mar Ecol Prog Ser 251:49-58

Weber LH, El-Shayed SZ, Hampton I (1986) The variance spectra of phytoplankton, krill and water temperature in the Antarctic Ocean south of Africa. Deep-Sea Res 33:1327-1343

Submitted: November 26, 2003; Accepted: February 3, 2005 Proofs received from author(s): June 13, 2005 